\title{
Huaier Extract Granule
}

National Cancer Institute

\section{Source}

National Cancer Institute. Huaier Extract Granule. NCI Thesaurus. Code C125001.

An orally bioavailable traditional Chinese medicine (TCM) composed of a granule containing an aqueous extract of Trametes robiniophila murr (Huaier), a mushroom found on hardwood tree trunks, with potential antineoplastic and anti-angiog enic activities. Although the exact mechanism of action through which Huaier exerts its effects is largely unknown, upon administration, this agent induces cell cycle arrest and apoptosis, and inhibits proliferation and migration of susceptible cancer cells through the modulation of various signal transduction pathways involved in carcinogenesis and angiogenesis. 